\title{
Pinus pinea (L.) nut and kernel productivity in relation to cone, tree and stand characteristics
}

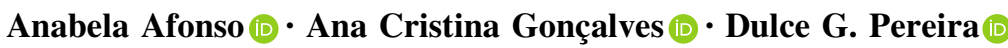

Received: 2 November 2019/Accepted: 14 July 2020/Published online: 21 July 2020

(C) Springer Nature B.V. 2020

\begin{abstract}
Pinus pinea stands have been identified as one of the target species for agroforestry systems in Europe. Its fruit yield is of importance to the local development, especially in the Mediterranean basin, due to its highly nutritional kernels and its economic value. The objectives of this study were to analyze the relation between pine nut and kernel weight and its efficiencies in relation to cone and tree traits for different stand structures. The statistical analysis was carried out with correlation, multiple correlation analysis, hurdle-gamma regression, principal component and cluster analysis, with a dataset of about 3300 cones collected in four plots and 3 years. The results indicate that pine nut and kernel and its efficiencies depend on stand structure, year and tree
\end{abstract}

A. Afonso $(\bowtie) \cdot$ D. G. Pereira

Departamento de Matemática, Escola de Ciências e Tecnologia, Centro de Investigação em Matemática e Aplicações, Instituto de Investigação e Formação Avançada, Universidade de Évora, Rua Romão Ramalho 59, 7000-671 Évora, Portugal e-mail: aafonso@uevora.pt

D. G. Pereira

e-mail: dgsp@uevora.pt

\section{A. C. Gonçalves}

Departamento de Engenharia Rural, Escola de Ciências e Tecnologia, Mediterranean Institute for Agriculture, Environment and Development (MED), Instituto de Investigação e Formação Avançada, Universidade de Évora, Apartado 94, 7002-544 Évora, Portugal e-mail: acag@uevora.pt characteristics. The principal component analysis and the cluster analysis enabled the identification of four groups of trees related to the pine nut and kernel efficiencies. The higher efficiencies per tree are attained in stands managed for fruit production, increasing with the decrease of the density.

Keywords Hurdle-gamma regression - Pine nut and kernel efficiency · Principal component analysis · Stem and crown diameter $\cdot$ Weight

\section{Introduction}

Agroforestry and silvopastoral systems combining forest trees, agriculture (e.g., pasture) and grazing, are known for the balance between facilitation and competition, thus enabling to optimize the use of the growing space (Jose et al. 2019). The several products and yields derive in economically viable systems (Jose et al. 2004, 2019; Eichhorn et al. 2006; Cubbage et al. 2012; Nerlich et al. 2013; Pasalodos-Tato et al. 2016; Miah et al. 2018). The different components of the system are designed to optimize the spatial and temporal use of the growing space (Jose et al. 2019). It includes maintaining or improving pasture and forage quantity and quality (Orefice et al. 2019; Pang et al. 2019a, b), especially under drought conditions (Eichhorn et al. 2006; Ford et al. 2019) while 
maintaining tree productivity. These systems enhance biomass and carbon storage (Cubbage et al. 2012; Pantera et al. 2018; Adhikari et al. 2019; Aryal et al. 2019; López-Santiago et al. 2019) provide several ecosystem services such as regulation of microclimate, hydrological and nutrient cycling, soil conservation, reduction of fire risk and a range of social and cultural services (Reisner et al. 2007; Jose 2009; Cubbage et al. 2012; Miah et al. 2018; Pantera et al. 2018; Jose et al. 2019; Orefice et al. 2019). The European Mediterranean countries have the largest areas of agroforestry and silvopastoral systems (den Herder et al. 2017) and one of the target forest tree species for this system is Pinus pinea (Reisner et al. 2007).

Pinus pinea L. (umbrella pine) forest stands are usually managed as agroforestry systems, providing several products (Agrimi and Ciancio 1994; Calama et al. 2011; Nerlich et al. 2013). The stands have frequently low density and fruit is their main production (Agrimi and Ciancio 1994; Mutke et al. 2012). Fruit production presents inter-annual variability (Mutke et al. 2005a; Calama et al. 2011) in cycles of 3-6 years (Agrimi and Ciancio 1994). In the Mediterranean countries of Europe, umbrella pine nuts are economically important because of the high nutritional value, due to the high protein, carbohydrate, fat, vitamin and mineral content of the kernels (e.g., Cañellas et al. 2000; Nergiz and Dönmez 2004; Nasri and Triki 2007; Costa et al. 2008; Evaristo et al. 2008, 2010).

The estimation of cone and seed production are of primordial importance for tree regeneration (Redmond et al. 2016). In conifers in general, and in Pinus spp. in particular, the number of cones per tree, the number of pine nuts per cone and the seed efficiency (defined as the percent of the number of fully developed pine nuts in relation to the total number of pine nuts per cone) are determinant for the seed availability. In literature was reported a wide variability of cone production per tree for pine species (e.g., Agrimi and Ciancio 1994; Mutke et al. 2005a; Zlotin and Parmenter 2008; Ganatsas and Thanasis 2010; Gonçalves et al. 2017), as well as for the number of pine nuts per cone and the seed efficiency for Pinus strobus (Noland et al. 2006; Owens and Fernando 2007; Parker et al. 2013), Pinus sylvestris (Bilir et al. 2008), Pinus albicaulis (Owens et al. 2008), and Pinus pinea (Saraiva 1997; Montero et al. 2004; e.g., Calama and Montero 2007; Evaristo et al. 2008, 2010; Ganatsas et al. 2008). This variability is related with soil fertility and climate change. Several studies for Pinus spp. referred that the increase in soil nutrients availability, whether by silvicultural practices (e.g., thinning or cuts) or fertilization, produced a larger number of cones and pine nuts (Turner et al. 2007; Ortiz et al. 2012) as pines under low nutrient availability invested their resources first on growth and postpone their fruit production (Goubitz et al. 2002; Eugenio and Lloret 2006). Climate change, with temperature rise and changes in rainfall patterns, led to a cone yield reduction (Mutke et al. 2005a).

For umbrella pine the number of nuts per cone varied from 2 to 183 and their weight ranged from 28.4 to $57.1 \mathrm{~g}$ (Saraiva 1997; Montero et al. 2004; Calama and Montero 2007; Evaristo et al. 2008; Ganatsas et al. 2008). Also, several authors (Calama and Montero 2007; Evaristo et al. 2008; Ganatsas et al. 2008; Boutheina et al. 2013) referred a rate of undeveloped pine nut per cone ranging between 2 and 34\%. Kernel weight per cone varied between 10 and $27 \mathrm{~g}$ (Saraiva 1997; Evaristo et al. 2008).

Many studies have been made on umbrella pine cone production whether on quantity or on spatial and temporal variability (e.g., Montero et al. 2004; Calama and Montero 2007; Calama et al. 2008, 2011; Ganatsas et al. 2008; Gonçalves and Pommerening 2012), on mechanical harvest (e.g., Castro-García et al. 2012; Gonçalves et al. 2016), on the effect of pest on cones (Calama et al. 2017), on the effect of water and light in the seedlings and trees survival and growth (e.g., Pardos et al. 2009; Calama et al. 2013; Manso et al. 2014; De-Dios-García et al. 2015; Mayoral et al. 2016), and on cone, pine nut and kernel characteristics (e.g., Agrimi and Ciancio 1994; Saraiva 1997; Nergiz and Dönmez 2004; Evaristo et al. 2008; Ganatsas et al. 2008; Evaristo et al. 2010). Other studies reported a high variability of the number of pine nuts and kernels per cone and their efficiencies (Calama and Montero 2007; Evaristo et al. 2008; Ganatsas et al. 2008). Additionally, the profitability of umbrella pine stands managed for timber and fruit is related to the number of cones per tree and the cone market price (PasalodosTato et al. 2016). The shortcoming of these studies is that they used a limited number of cones and did not related them with the tree dendrometric variables and stand structure. 
There are many variables to measure tree' dimensions and stand structure. Also, each tree has a large variability in cone, pine nut and kernel productions, which may correspond to a large data set. To analyze this kind of data set several statistical techniques are available. Principal component analysis (PCA) has been used in forestry to narrow down a large variable set to the most explaining variables (del Campo et al. 2007; Liu et al. 2018; Bueis et al. 2018). Several authors used PCA to select a subset of environmental variables that accounted for the highest variability of edaphic, climatic and physiographic variables on tree establishment and growth (e.g., del Campo et al. 2007; Bueis et al. 2018) while others used it to identify groups with different traits (e.g., Liu et al. 2018) and others still correlated site and nut production variables (e.g., del Campo et al. 2007; Ugese et al. 2010). Hurdle models were used to model cone production variation of Pinus palustris Mill. and dealt with the high occurrence of zeros (Haymes and Fox 2012). Hurdle models have the advantage of providing further insight into production dynamics by analyzing those factors driving production occurrence and yield separately (Taye et al. 2016).

The main goal of this study is to understand the relations of stand type, tree' dimensions and cone weight on the number and weight of pine nut and weight of kernel per cone and its efficiencies with a large data set. In more detail, the hypotheses of this study are: (1) heavier cones have higher number, weight and efficiency of fully developed pine nuts; (2) trees with large diameter at breast height and crown diameter produce higher number, weight and efficiency of fully developed pine nuts per cone; (3) heavier cones have higher kernel weight and efficiency; (4) trees with large diameter at breast height and crown diameter produce higher kernel weight and efficiency; (5) groups of trees can be identified as function of the number and weight of pine nuts and kernels or its efficiencies, and stand structure and tree dendrometric variables.

\section{Materials and methods}

Materials

The data was collected in four plots located in Alcácer do Sal, Portugal; plot 1, Herdade do Pai Sobrado; plot
2, Mata de Valverde; plot 3, Herdade do Monte Novo; and plot 4, Quinta de Sousa (Table 1). The plots are representative of agroforestry (1,3, and 4) and forestry (2) systems. Plots 1, 3 and 4 are managed as silvopastoral systems, with wide spacing to promote stem and crown diameter growth, mainly through thinning. Their productions are fruit and cattle grazing on natural (plots 1 and 3) and artificial (plot 4) pastures. Plot 2 is a pure even-aged stand, with a silvicultural model that includes thinning and pruning to promote stem growth. Plot 2 has total and stem height higher than the other tree plots, $46-51 \%$ and 20-30\%, respectively. Inversely, crown radii are in average $15-23 \%$ smaller in plot 2 than in plots 1,3 and 4. None of the plots is irrigated, grafted or fertilized, except for plot 4 where the understory pasture is fertilized. All plots were pruned and control of natural vegetation was carried out periodically to reduce fire risk, with cycles depending on their development. The following dendrometric variables were measured in all trees in each plot, for all individuals with diameter at breast height larger than $10 \mathrm{~cm}$ : diameter at breast height, total height, stem height, height of the beginning of the crown, and four crown radii in the north, south, east and west directions. In 120 trees per plot cone were harvested, 30 manually and 90 mechanically, during three years. Trees were allocated to manual and mechanical harvest through a random stratified sampling, with strata defined by $0.1 \mathrm{~m}$ diameter at breast height classes (for details see Gonçalves et al. 2016). In each harvest, 3 cones were selected randomly per tree (Gonçalves et al. 2017).

The pine nuts were extracted from the dry cones, cleaned, separated in fully developed pine nuts and undeveloped pine nuts, weighted and counted. The pine nuts from each cone were broken manually and the kernels weighted. Weights were recorded with a precision scale to $1 \mathrm{mg}$. Seed efficiency per cone $\left(s_{e f}\right.$, Eq. 1 , in $\%$ ) was computed by the number of fully developed pine nuts in relation to the total number of pine nuts. Pine nut efficiency $\left(P N_{e f w}\right.$, Eq. 2 , in \%) and kernel efficiency $\left(K_{\text {efw }}\right.$, Eq. 3, in \%) per cone on a fresh weight basis were defined as the relation between the fully developed pine nut weight and kernel weight per cone in relation to the cone fresh weight. 
Table 1 Plots locations and characteristics

\begin{tabular}{|c|c|c|c|c|}
\hline \multirow[t]{2}{*}{ Variable } & \multicolumn{4}{|l|}{ Plot } \\
\hline & 1 & 2 & 3 & 4 \\
\hline Central coordinates & $\begin{array}{l}38^{\circ} 21^{\prime} 34^{\prime \prime} \mathrm{N} \\
8^{\circ} 31^{\prime} 07^{\prime}, \mathrm{W}\end{array}$ & $\begin{array}{l}38^{\circ} 19^{\prime} 28^{\prime \prime} \mathrm{N} \\
8^{\circ} 32^{\prime} 36^{\prime \prime} \mathrm{W}\end{array}$ & $\begin{array}{l}38^{\circ} 29^{\prime} 35^{\prime \prime} \mathrm{N} \\
8^{\circ} 38^{\prime} 35^{\prime \prime} \mathrm{W}\end{array}$ & $\begin{array}{l}38^{\circ} 33^{\prime} 55^{\prime \prime} \mathrm{N} \\
8^{\circ} 35^{\prime} 15^{\prime \prime} \mathrm{W}\end{array}$ \\
\hline System & Agroforestry & Forestry & Agroforestry & Agroforestry \\
\hline Main production & Fruit & Timber & Fruit & Fruit \\
\hline Soils & Chromic regosols & Chromic podzol regosols & Chromic regosols & Cambic podzol regosols \\
\hline Composition & Pure & Pure & Pure & Pure \\
\hline Structure & Even-aged & Even-aged & Even-aged & Even-aged \\
\hline Mean age (years) & $\approx 60$ & $\approx 60$ & $\approx 60$ & $\approx 60$ \\
\hline Plot area (ha) & 1.5 & 0.6 & 1.6 & 2.0 \\
\hline Number of trees (trees $\mathrm{ha}^{-1}$ ) & 95 & 233 & 103 & 66 \\
\hline Basal area $\left(\mathrm{m}^{2} \mathrm{ha}^{-1}\right)$ & 9.8 & 25.3 & 10.7 & 8.1 \\
\hline
\end{tabular}

$s_{\text {ef }}=\frac{\text { Number of fully developed pine nuts per cone }}{\text { Total number of pine nuts per cone }}$

$P N_{\text {efw }}=\frac{\text { Fully developed pine nut weight per cone }}{\text { Cone fresh weight }}$

$K_{\text {efw }}=\frac{\text { Kernel weight per cone }}{\text { Cone fresh weight }}$

Data set is composed of pine nuts (seed with shell) and kernels (seed without shell) of 3313 cones. The data set used is valuable for two reasons. First, it is composed by a large number of samples thus enabling data to include most of the variability of pine nuts and kernels per cone. Second, harvests were done in stands not affected by Leptoglossus occidentalis, resulting in a pre-damage data that can be used as a standard or baseline for the diagnosis of the stands affected by the seed bug.

\section{Statistical analysis}

Normality was evaluated with Shapiro-Wilk test and homogeneity of variance with Levene test. When the assumptions of normality and homogeneity of variance were not met, nonparametric tests were used in the analysis. Linear correlations between fresh and dry cone weight, number and weight of pine nuts per cone, weight of kernels per cone and pine nut, kernel and seed efficiencies were evaluated using Pearson's $r$ coefficient. Kruskal-Wallis test, followed by Fisher LSD multiple comparisons test applied to ranks with Holm method for adjusting p values (Wright 1992; Sheskin 2007), were used to test differences in the number and weight of pine nuts per cone and in its efficiencies between plots and years. The analysis of the differences in the average number of undeveloped pine nuts per cone between trees was done with a hurdle-gamma regression (Zuur and Ieno 2016), due to the high occurrence of zeros in the dataset. The explanatory variables considered were year, plot, average of cone fresh weight per tree, average of the cone moisture content per tree (quotient between the difference of fresh and dry cone weight and cone fresh weight), average number of pine nuts fully developed per cone and tree, average seed efficiency, tree characteristics (diameter at breast height, total height, stem height, crown length, height of the beginning of the live crown, crown diameter) as well as the second order interactions. Collinearity was evaluated with Generalized Variation Inflation Factor for the model's main effects. Likelihood ratio tests were used to compare goodness of fit between nested models and Akaike's information criterion for non-nested models. Additionally, Hosmer-Lemeshow test and pseudo $R^{2}$ MacFadden were used to assess goodness of fit in logistic part and the adjusted $R^{2}$ for the gamma part. Principal component analysis (PCA) (Johnson and 
Wichern 2007) was used in multivariate data analysis of average efficiency production per tree (fresh cone weight, pine nut, kernel and seed efficiencies) and tree characteristics. Original variables were standardized to zero mean and unit variance, because they were measured in different units. Year and plot were considered as supplementary variables. Kaiser's rule was used to decide how many components were to be retained: only the principal components with eigenvalues greater than one were selected. In addition, to identify clusters of trees that may correspond to the profiles identified with PCA, it was applied a nonhierarchical cluster analysis (NHCA), considering as variables the coordinates of the trees in the retained components. The statistical analysis was performed using R Project, version 3.3.0 (R Core Team 2016). The level of significance used was 0.05 .

\section{Results}

Pine nuts

More than half of the cones (54\%) had only fully developed pine nuts. For the remaining 46\%, 28.7\% had up to 5 undeveloped pine nuts, $7.5 \%$ from 6 to 10 , $7.1 \%$ from 11 to 30 , and $2.7 \%$ more than 30 . The overall mean proportion of undeveloped pine nuts was $5.4 \%$, ranging from 0.7 to $93.1 \%$, corresponding to an average of seed efficiency of $94.6 \%$. The overall number of fully developed pine nuts per cone ranged from 1 to 152, with a median of 78 (Table 2). The weight of these pine nuts ranged from 0.8 to $124.4 \mathrm{~g}$, with a median of $54.8 \mathrm{~g}$ (Table 2) that corresponded to pine nut efficiency between 16.2 and $21.4 \%$. Noteworthy is that half of the samples had a number of pine nuts between 57 and 98 (IQR) and a weight between 36.5 and $70.5 \mathrm{~g}$ (IQR). The weight and the number of pine nuts per cone were strongly linear positive correlated (Pearson's $r=0.891$ ). Very strong and strong linear positive correlations were found between fresh and dry cone weight with the number and weight of fully developed pine nuts per cone (Table 3). The number and weight of fully developed pine nuts per cone differed significantly between plots $\left(\chi_{3}^{2}=1147.7\right.$, $p<0.001$ and $\chi_{3}^{2}=1128.2, p<0.001$, respectively) and between years $\left(\chi_{2}^{2}=158.5, p<0.001\right.$ and $\chi_{2}^{2}=212.8, p$ $<0.001$, respectively). Plot 4 had the heaviest pine nuts and the highest pine nut efficiency while plot 2 had less and lighter pine nuts as well as the lowest pine nut efficiency (Table 2). The pine nut efficiency followed the same pattern as the weight and number of fully developed pine nuts.

Total height, crown length, height of the beginning of the live crown, crown diameter, and the average of the cone moisture content per tree did not contribute to explain either the existence or the average number of undeveloped pine nuts per cone and per tree (Table 4). The odds of a cone having undeveloped pine nuts were lower for trees in plot 2 and higher for trees in plot 4 and plot 1, in this last plot only in 2003 (Table 4). The odds were highest in 2005 in all plots. For all plots and years, the odds were lower for cones with high number of pine nuts fully developed, however these odds increased with the stem height of the tree.

Among the cones with undeveloped pine nuts, the average number of undeveloped pine nuts per cone and per tree decreased $\exp (-0.008)=0.992$ times with a unit increase in diameter at breast height and increased $\exp (0.656)=1.927$ times with a unit increase in stem height (Table 4). For each unit increase in seed efficiency this average decreased $17.2 \%(=(1-\exp (-0.075)) \times 100)$. In all plots, this average was smaller in year of 2004 and higher in 2005. With a unit increase in the average of the fresh cone weight per tree the average number of pine nuts undeveloped increased 1.004 times in plot 2, 1.002 times in plot 1 and 1.992 times in plot 4 , and decreased 0.926 times in plot 3 .

The number of fully developed pine nuts differed significantly among diameter at breast height classes (grouped in $0.1 \mathrm{~m}$ classes) $\left(\chi_{4}^{2}=14.249, p=0.007\right)$ and a marginally significant difference was detected in the weight of fully developed pine nuts $\left(\chi_{4}^{2}=8.363, p=0.079\right)$. A similar trend was observed for crown diameter (grouped in $1 \mathrm{~m}$ classes) in the number of pine nuts $\left(\chi_{10}^{2}=22.340, p=0.013\right)$, with significant differences in pine nut weight among crown diameter classes $\left(\chi_{10}^{2}=41.538, p<0.001\right)$. The pine nut efficiency did not differ with diameter at breast height $\left(\chi_{4}^{2}=4.691, p<0.320\right.$; Fig. 1 left $)$, however differed with crown diameter $\left(\chi_{10}^{2}=34.951, p<0.001\right.$; Fig. 1 right $)$. The trees with diameter at breast height between 0.4 and $0.6 \mathrm{~m}$ were those with the lowest number of pine nuts. The trees 


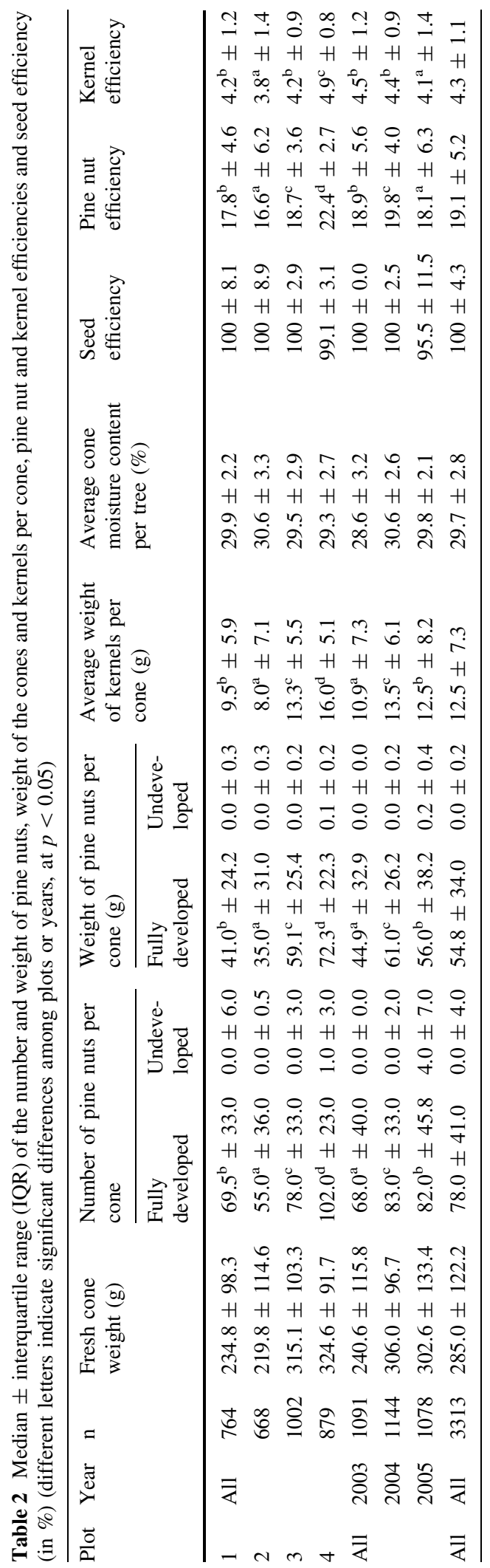


Table 3 Pearson correlation matrix between fresh and dry cone weight, with the number and weight of fully developed pine nuts and weight of kernels per cone. All correlations are significant at $1 \%$

\begin{tabular}{|c|c|c|c|c|c|c|c|}
\hline \multirow[t]{2}{*}{ Plot } & \multirow[t]{2}{*}{ Year } & \multicolumn{3}{|c|}{ Fresh cone weight $(\mathrm{g})$} & \multicolumn{3}{|c|}{ Dry cone weight (g) } \\
\hline & & $\begin{array}{l}\text { Number of pine } \\
\text { nuts }\end{array}$ & $\begin{array}{l}\text { Weight of pine } \\
\text { nuts }(\mathrm{g})\end{array}$ & $\begin{array}{l}\text { Weight of } \\
\text { kernels }(\mathrm{g})\end{array}$ & $\begin{array}{l}\text { Number of pine } \\
\text { nuts }\end{array}$ & $\begin{array}{l}\text { Weight of pine } \\
\text { nuts }(\mathrm{g})\end{array}$ & $\begin{array}{l}\text { Weight of } \\
\text { kernels }(\mathrm{g})\end{array}$ \\
\hline 1 & All & 0.718 & 0.908 & 0.864 & 0.719 & 0.911 & 0.867 \\
\hline 2 & & 0.772 & 0.911 & 0.840 & 0.774 & 0.917 & 0.853 \\
\hline 3 & & 0.728 & 0.891 & 0.854 & 0.722 & 0.902 & 0.865 \\
\hline \multirow[t]{2}{*}{4} & & 0.577 & 0.855 & 0.808 & 0.587 & 0.884 & 0.829 \\
\hline & 2003 & 0.722 & 0.926 & 0.893 & 0.717 & 0.934 & 0.901 \\
\hline \multirow[t]{2}{*}{ All } & 2004 & 0.702 & 0.887 & 0.843 & 0.713 & 0.898 & 0.846 \\
\hline & 2005 & 0.766 & 0.905 & 0.897 & 0.772 & 0.912 & 0.904 \\
\hline All & All & 0.747 & 0.905 & 0.874 & 0.751 & 0.916 & 0.885 \\
\hline
\end{tabular}

Table 4 Hurdle-gamma regression estimated coefficients (B), standard errors (SE) and $p$ values, for the variable associated with the average number of pine nuts per tree undeveloped

\begin{tabular}{|c|c|c|c|c|c|c|}
\hline \multirow[t]{2}{*}{ Variables } & \multicolumn{3}{|c|}{ Logistic part $^{\mathrm{a}}$} & \multicolumn{3}{|c|}{ Gamma part $^{\mathrm{b}}$} \\
\hline & $\mathrm{B}$ & SE & $p$ & $\mathrm{~B}$ & SE & $p$ \\
\hline Constant & 0.047 & 1.048 & 0.964 & 6.933 & 0.211 & $<0.001$ \\
\hline \multicolumn{7}{|l|}{ Year (ref: 2004) } \\
\hline 2003 & 0.648 & 0.665 & 0.330 & 0.593 & 0.069 & $<0.001$ \\
\hline 2005 & 14.144 & 5.086 & 0.005 & 0.710 & 0.052 & $<0.001$ \\
\hline \multicolumn{7}{|l|}{ Plot (ref: 2) } \\
\hline 1 & 0.794 & 0.399 & 0.047 & 0.656 & 0.202 & 0.001 \\
\hline 3 & 0.786 & 0.344 & 0.022 & 0.131 & 0.237 & 0.579 \\
\hline 4 & 2.614 & 0.465 & $<0.001$ & 0.878 & 0.272 & 0.001 \\
\hline Stem height & -0.163 & 0.147 & 0.268 & 0.656 & 0.202 & 0.001 \\
\hline Diameter at breast height & & & & -0.008 & 0.002 & 0.001 \\
\hline Average fresh cone weight & & & & 0.004 & 0.001 & $<0.001$ \\
\hline Average number of pine nuts & -0.021 & 0.012 & 0.086 & & & \\
\hline Average seed efficiency & & & & -0.075 & 0.002 & $<0.001$ \\
\hline Year $2003 \times$ Plot 1 & 1.792 & 0.388 & $<0.001$ & & & \\
\hline Year $2003 \times$ Plot 4 & & & & -0.427 & 0.143 & 0.003 \\
\hline Year $2005 \times$ Plot 4 & & & & -0.285 & 0.086 & 0.001 \\
\hline Year $2003 \times$ Average number of pine nuts & -0.039 & 0.008 & $<0.001$ & & & \\
\hline Year $2005 \times$ Average number of pine nuts & -0.061 & 0.056 & 0.273 & & & \\
\hline Stem height $\times$ Average number of pine nuts & 0.005 & 0.002 & 0.010 & & & \\
\hline Average fresh cone weight $\times$ Plot 1 & & & & -0.002 & 0.001 & 0.019 \\
\hline Average fresh cone weight $\times$ Plot 3 & & & & -0.001 & 0.001 & 0.126 \\
\hline Average fresh cone weight $\times$ Plot 4 & & & & -0.002 & 0.001 & 0.005 \\
\hline
\end{tabular}

a $\quad \mathrm{N}=1148, \quad \mathrm{R}^{2} \quad$ McFadden $=0.406, \quad$ Hosmer-Lemeshow test: $\chi_{8}^{2}=1.474, \quad p=0.993, \quad$ AUC $=0.889, \quad$ sensivity $=73.6 \%$, specificity $=87.7 \%$, cutoff point $=0.642$

${ }^{\mathrm{b}} \mathrm{N}=747$, Adjusted $\mathrm{R}^{2}=0.821$ 


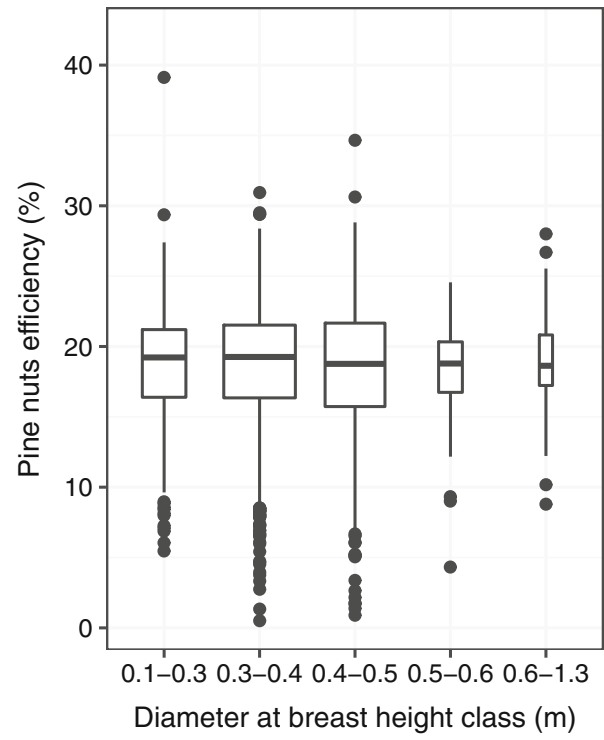

Fig. 1 Pine nut efficiency per diameter at breast height classes (left), and crown diameter classes (right) (different letters indicate significant differences in pine nut weight between

with the median crown diameters were those with the highest number and weight of pine nuts and efficiency.

Kernels

Per cone, the weight of kernels ranged between 0.2 and $27.7 \mathrm{~g}$ with a median of $12.5 \mathrm{~g}$ (IQR $=8.5-15.8 \mathrm{~g}$ ), which corresponded to a kernel efficiency between $3,7 \%$ and $4.9 \%$ (Table 2). The weight and efficiency of the kernels were lower in plot 2 and higher in plot 4 (Table 2). Per year analysis (Table 2) revealed that the heaviest kernels were attained in 2004 (IQR = $10.4-16.5 \mathrm{~g}$ ), followed by 2005 (IQR $=8.0-16.2 \mathrm{~g}$ ) and 2003 (IQR = 7.2-14.5 g), and presented a similar tendency to the weight of fresh cone. A different pattern was observed for kernel efficiencies where the highest efficiency occurred in 2003 (IQR $=3.8-5.0 \%$ ) and $2004(\mathrm{IQR}=3.9-4.8 \%)$, followed by 2005 $(\mathrm{IQR}=3.3-4.6 \%)($ Table 2$)$.

Fresh and dry cone weight were strongly and positively correlated with kernel weight per cone, and the strength of the correlation varied among plots and years (Table 3). The correlations with kernel efficiency were weaker, thought statistically significant (all Pearson's $r<0.55$ ). Per tree, the average kernel weight per cone was strongly and positively correlated with the average of the weight and the mean number of pine nuts fully developed per cone as well as with the diameter classes, at $p<0.05$ ). Boxes are drawn with widths proportional to the square-roots of the number of observations in the groups

average of dry cone weight (Table 5). Weaker but significant negative correlations were found between kernel weight and height of the beginning of the crown, stem height and total height, and a positive correlation between kernel weight and crown length and crown diameter. No significant correlation was found between kernel weight and diameter at breast height.

There was a statistically significant difference between the kernel weight by crown diameter classes $\left(\chi_{10}{ }^{2}=31.752, p<0.001\right)$ but not by diameter at breast height classes $\left(\chi_{4}^{2}=7.678, p<0.104\right)$. Trees with median crown diameters have heavier kernel per cone and also the highest variability in kernel weight. The kernel efficiency differed significantly by diameter at breast height classes $\left(\chi_{4}^{2}=11.026, p<0.026\right.$; Fig. 2 left) and by crown diameter classes $\left(\chi_{10}^{2}=38.431, p<0.001\right.$; Fig. 2 right $)$. The efficiency decreased with the increase of diameter at breast height but no marked trend in the efficiency was observed by crown diameter.

Effect of stand, tree and cone characteristics in pine nut and kernel weight

PCA and NHCA were applied to tree characteristics and pine nut and kernel average efficiencies, and the results are shown in the biplot graphs, PC1-PC2 
Table 5 Pearson's correlation matrix between the characteristics of the trees, cones, pine nuts and kernels

\begin{tabular}{|c|c|c|c|c|c|c|c|c|c|}
\hline & $\begin{array}{l}\text { Diameter } \\
\text { at breast } \\
\text { height }\end{array}$ & $\begin{array}{l}\text { Total } \\
\text { height }\end{array}$ & $\begin{array}{l}\text { Stem } \\
\text { height }\end{array}$ & $\begin{array}{l}\text { Height of } \\
\text { the } \\
\text { beginning } \\
\text { of the live } \\
\text { crown }\end{array}$ & $\begin{array}{l}\text { Crown } \\
\text { length }\end{array}$ & $\begin{array}{l}\text { Crown } \\
\text { diameter }\end{array}$ & $\begin{array}{l}\text { Average } \\
\text { of dry } \\
\text { cone } \\
\text { weight } \\
\text { per tree }\end{array}$ & $\begin{array}{l}\text { Average of the } \\
\text { mean number } \\
\text { of pine nuts } \\
\text { fully } \\
\text { developed per } \\
\text { cone and per } \\
\text { tree }\end{array}$ & $\begin{array}{l}\text { Average } \\
\text { of the } \\
\text { weight of } \\
\text { pine nuts } \\
\text { per cone } \\
\text { and per } \\
\text { tree }\end{array}$ \\
\hline Total height & $0.497 * *$ & & & & & & & & \\
\hline Stem height & 0.011 & $0.693 * *$ & & & & & & & \\
\hline $\begin{array}{l}\text { Height of the } \\
\text { beginning of } \\
\text { the live } \\
\text { crown }\end{array}$ & $0.146^{* *}$ & $0.742 * *$ & $0.827 * *$ & & & & & & \\
\hline Crown length & $0.442 * *$ & $0.218 * *$ & $-0.312 * *$ & $-0.481 * *$ & & & & & \\
\hline $\begin{array}{l}\text { Crown } \\
\text { diameter }\end{array}$ & $0.757 * *$ & $0.262 * *$ & $-0.230 * *$ & $-0.076^{*}$ & $0.467 * *$ & & & & \\
\hline $\begin{array}{l}\text { Average of dry } \\
\text { cone weight } \\
\text { per tree }\end{array}$ & 0.005 & $-0.194 * *$ & $-0.323 * *$ & $-0.460 * *$ & $0.430 * *$ & $0.133 * *$ & & & \\
\hline $\begin{array}{l}\text { Average of the } \\
\text { mean } \\
\text { number of } \\
\text { pine nuts } \\
\text { fully } \\
\text { developed } \\
\text { per cone and } \\
\text { per tree }\end{array}$ & $-0.060 *$ & $-0.364 * *$ & $-0.426^{* *}$ & $-0.533^{* *}$ & $0.306^{* *}$ & 0.025 & $0.771 * *$ & & \\
\hline $\begin{array}{l}\text { Average of the } \\
\text { weight of } \\
\text { pine nuts per } \\
\text { cone and per } \\
\text { tree }\end{array}$ & -0.017 & $-0.267 * *$ & $-0.381 * *$ & $-0.514 * *$ & $0.410 * *$ & $0.084 * *$ & $0.922 * *$ & $0.907 * *$ & \\
\hline $\begin{array}{l}\text { Average of the } \\
\text { weight of } \\
\text { kernels per } \\
\text { cone and per } \\
\text { tree }\end{array}$ & -0.033 & $-0.281 * *$ & $-0.369 * *$ & $-0.508 * *$ & $0.386^{* *}$ & $0.072 *$ & $0.896 * *$ & $0.878 * *$ & $0.964 * *$ \\
\hline
\end{tabular}

*Correlation is significant at the 0.05 level (2-tailed)

$* *$ Correlation is significant at the 0.01 level (2-tailed)

(Fig. 3 left) and PC2-PC3 (Fig. 3 right). The variables are represented by arrows and the trees by points colored according to their cluster. There were 3 principal components (PC) identified through eigenvalues larger than 1 and explained $79.1 \%$ of the total variance of the data.

The first component (PC1), containing the largest possible amount of information, was strongly correlated with the trees' dimensions (diameter at breast height, total height, stem height, height of the beginning of the live crown, crown length, crown diameter), cone fresh weight, pine nut and kernel efficiencies (Fig. 3 left). It was possible to name the PC1 as cone production intent, since it opposed fruit production efficiencies to tree height. The second component (PC2) associated diameter at breast height with the crown diameter. The third component (PC3) was related to seed efficiency and stem height (Fig. 3 right). In the plots it was possible to clearly identify 3 profiles (Fig. 3): P1) trees for timber production; P2) 


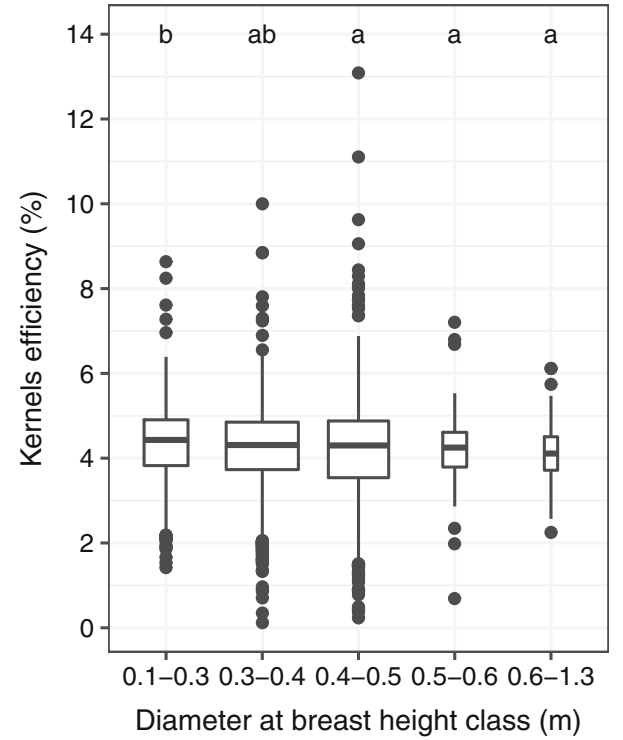

Fig. 2 Kernel efficiency per diameter at breast height classes (left), and crown diameter classes (right) (different letters indicate significant differences in kernel weight between

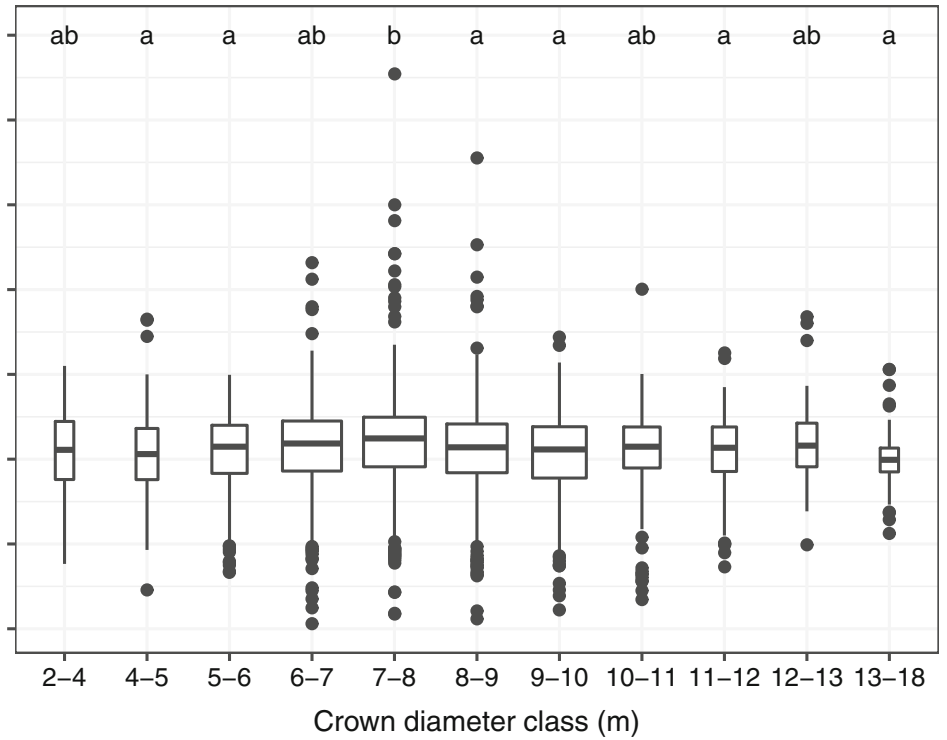

diameter classes, at $p<0.05$ ). Boxes are drawn with widths proportional to the square-roots of the number of observations in the groups
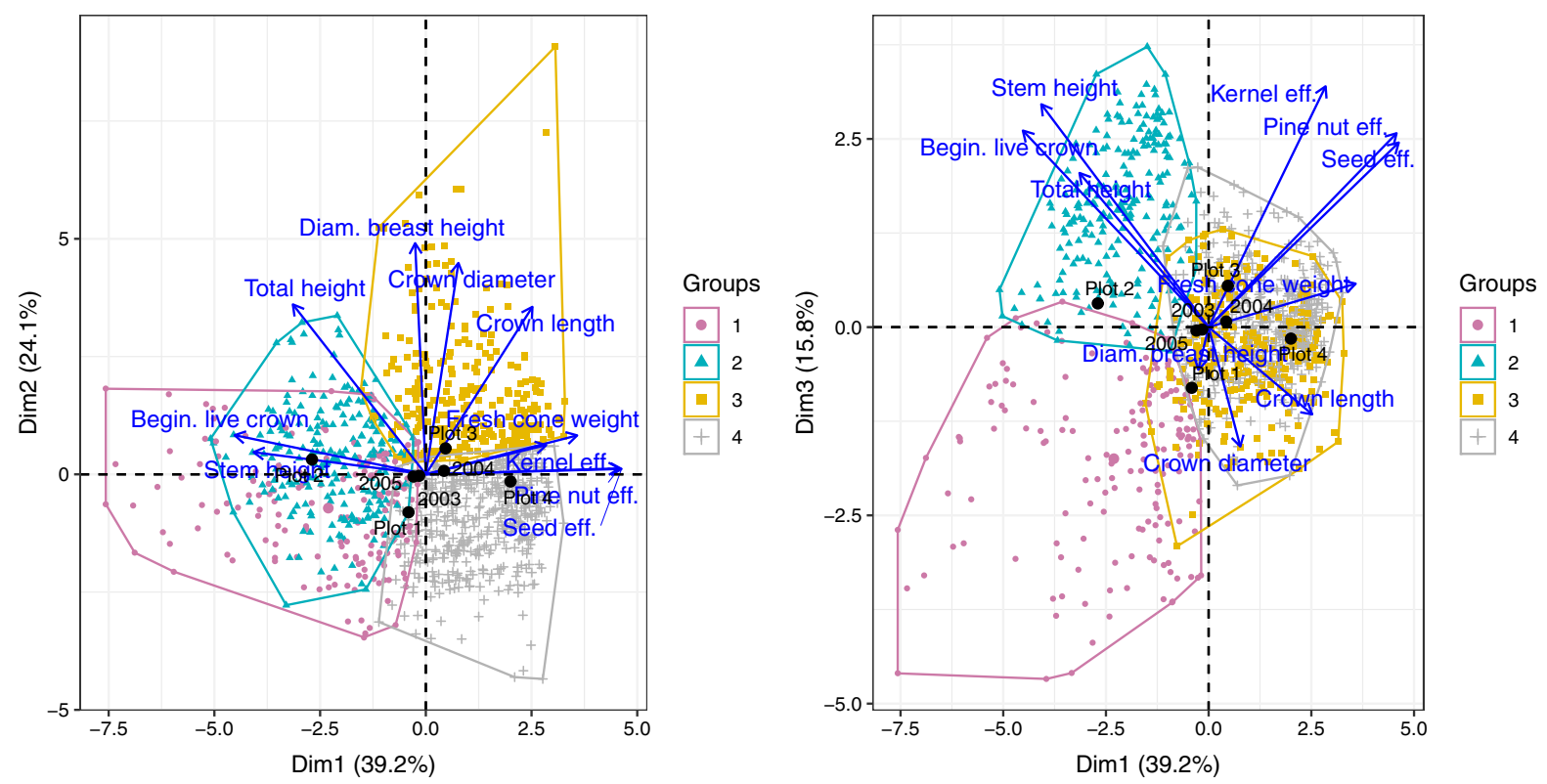

Fig. 3 Biplot of trees and variables in the first three dimensions of principal component analysis of tree characteristics and their average efficiency production. Biplot of PC1 and PC2 (left), biplot of PC1 and PC3 (right). The clusters identified by NHCA are also represented

large trees with high pine nut and kernel efficiencies; P3) small trees with high pine nut and kernel efficiencies. Trees in plot 2 were linked to profile 1 and trees in plot 4 to profile 3 . The plots managed for fruit production (plots 1, 3 and 4) had higher pine nut and kernel weights and efficiencies when compared with that managed for timber (plot 2). The years were not related with the obtained components. Four homogeneous groups of trees were identified with NHCA, which corresponded to the aforementioned profiles and are represented in Fig. 3: G1) The trees in this cluster had low seed, pine nut and kernel 
efficiencies which is associated to P1. Cluster G1 has $15 \%$ of the total number of trees. Half of the trees of this cluster were from plot 1 , which corresponded to one third of the trees of this plot; G2) Clustered nearly $20 \%$ of the total number of trees. The trees in cluster G2 had characteristics similar to those of G1, but were taller trees. Nearly $80 \%$ of the trees from plot 2 belonged to $\mathrm{G} 2$, and $86 \%$ of the trees in $\mathrm{G} 2$ were from plot 2; G3) Cluster G3 has $25 \%$ of the total of trees. The characteristics of the trees in this cluster corresponded to those described in P2. More than half of the trees of this group were from plot 3 ; G4) Trees in cluster G4 had the characteristics of P3 which corresponded to $40 \%$ of the total number of trees. Almost $70 \%$ of the trees from plot 4 belonged to G4.

\section{Discussion}

Pine nuts

The number and weight of fully developed pine nuts per cone as well as their efficiency differed significantly among years. The absence of relation between annual, spring and autumn precipitation and the number, weight and efficiency of pine nuts, can be partially explained by the air relative humidity. On average, the air relative humidity is higher than $70 \%$ per year as well as for spring, and is higher than $60 \%$ for the dry months, June, July and August (SNIRH 2007), which may reduce water stress. This reduction can be due to the deposition of water in the leaves that cool them, to the absorption of water by the leaves, and to the mist precipitation with the increase of water in the soil (Baguskas et al. 2016). Thus, the inter-annual tree irregular fruiting patterns of umbrella pine could be the determinant factor for the variability of production (Agrimi and Ciancio 1994; Saraiva 1997; Mutke et al. 2005b).

There are significant differences among different stand structures, for the number and weight of fully developed pine nuts per cone as well as for their efficiencies. The highest number of pine nuts, the heaviest weight of pine nuts and kernels per cone, was attained in the stand with lowest density (cf. Gonçalves et al. 2017). The overall number of fully developed pine nuts per cone in this study (1-152 pine nuts per cone) was in the range presented by other authors (Saraiva 1997; Montero et al. 2004; Calama and Montero 2007; Evaristo et al. 2008; Ganatsas et al. 2008; Boutheina et al. 2013). However, the proportion of fully developed pine nuts $(94.6 \%)$ is higher (75.6-90.0\%) than the referred by other authors for umbrella pine (Saraiva 1997; Ganatsas et al. 2008; Boutheina et al. 2013). It is also higher than that reported for other timber oriented pine species, for example $75-78 \%$ for Pinus strobus (Parker et al. 2013), 63\% for Pinus sylvestris (Bilir et al. 2008) 59\% for Pinus albicaulis (Owens et al. 2008) and 80-83\% for Pinus halepensis (Ortiz et al. 2012). The proportion of fully developed pine nuts is related to stand structure, year, stem height and average of number of pine nuts per cone. The stands with low density have trees with large diameters at breast height and crown diameters, and produced heavier cones which in turn had more and heavier fully developed pine nuts. The results of this study show that the trees with diameter at breast height lower than $0.4 \mathrm{~m}$ and crown diameter between 6 and $9 \mathrm{~m}$ were those with the highest number and weight of fully developed pine nuts, which correspond to the diameter at breast height and crown diameter classes with the heaviest cones (cf. Gonçalves et al. 2017). There were also differences in the proportion of fully developed pine nuts among years (years). This could be, at least partially, explained by the inter-annual variability in cone production (Agrimi and Ciancio 1994; Saraiva 1997; Mutke et al. 2005b; Calama et al. 2008; Rodrigues et al. 2014; Gonçalves et al. 2017). The position of the trees in the stand vertical profile may also affect their fruiting pattern. Stem height and, thus, tree crown position in the canopy may, at least partially, justify the decrease of fully developed pine nuts per cone. This can be related to pollination as umbrella pine is wind pollinated, in the upper canopy layer less pollen may reach the female flowers, with the consequent decrease of fully developed pine nuts per cone (Mutke et al. 2012).

The positive correlations between cones and pine nut weight and its efficiencies indicated that the heavier the cone the heavier the pine nut weight and the higher the efficiency. Similarly, Sirois (2000) for Picea mariana, Parker et al. (2013), Noland et al. (2006) and Rajora et al. (2002) for Pinus strobus and Bilir et al. (2008) for Pinus sylvestris, reported that the larger the cones the larger the number of pine nuts and the higher the number of fully developed pine nuts. In this study the higher the crown diameter the heavier the pine nuts per cone. Likewise, Parker et al. (2013) 
reported a positive correlation between crown area and pine nut production for Pinus strobus. These relations seem to be linked to stand structure, especially with vigorous trees with large crowns and nutrient availability for fruit and seed development (Rajora et al. 2002; Noland et al. 2006). The weakest correlations found in 2004, between fresh cone weight with the number of fully developed pine nuts per cone and seed efficiency, could be, at least partially, explained by the higher cone moisture content due to rainfall prior to harvest (cf. Gonçalves et al. 2017).

\section{Kernels}

Kernel weight and efficiency differed among plots and years. There seems to be a similar trend between pine nut and kernel weight per cone, with larger values for the heavier cones, which in turn are found in the plots with lower density. According to Gonçalves et al. (2017) the heavier cones come from stands with low competition between trees. Considering that plots are under a climate with a dry season (from May/June to September), characteristic of the Mediterranean region, lower densities enable less water stress, as referred for other pine species by some authors (Bueis et al. 2018). As cone, pine nut and kernel yield is affected by the amount of water available (Mutke et al. 2005a), the lower densities tend to promote heavier cones with more fully developed pine nuts and kernels.

Strong positive correlations were found between fresh and dry cone weight with kernel weight per cone and weak positive linear correlation with kernel efficiency. Similar results were reported for other pine species (Rajora et al. 2002; Noland et al. 2006; Bilir et al. 2008). Noland et al. (2006) suggest that these results denote high efficiency of pollination and the allocation of resources to the development of the kernels. Kernel weight per cone seemed to be linear independent of diameter at breast height, while kernel efficiency decreased with the increase of the diameter at breast height. In the four plots the trees with larger diameters were also the tallest. It seems that crown diameter affects kernel weight and efficiency.

Plot 4 has the highest pine nut number as well as the highest pine nut and kernel weight and efficiencies per cone. When compared to the other plots, the difference could be related to the pasture fertilization that benefit the umbrella pine trees and their fruiting. A similar trend is referred by Turner et al. (2007) and Ortiz et al. (2012).

Effect of stand, tree and cone characteristics in pine nut and kernel weight

PCA identified three profile and NHCA four groups of trees, using tree dimensions and cone weight, as function of the pine nut and kernel weight and efficiency. The higher pine nut and kernel weights were associated to the plots with low density and trees in free growth, whether with small or large stem and crown diameters. As plots are under similar soil and climatic conditions, it seems that competition among trees for light, water and nutrients, were the drivers of the weight and efficiency of pine nuts and kernels. Some authors refer the primordial role of water availability for growth, cone yield and pine nut production of Pinus halepensis (del Campo et al. 2007; Bueis et al. 2018). In this study the higher pine nut and kernel weights and efficiencies are attained in the plots with the low densities, and thus with higher growing space and lower competition per tree. In a simulation study Pasalodos-Tato et al. (2016) attained a similar trend.

\section{Conclusions}

The weight and efficiency of pine nuts and kernels at tree level depends on the stand structure and year. Significant correlations were found between cone fresh weight and the number of pine nuts, the weight of pine nuts and kernels. Thus, from a silvicultural perspective, practices, such as thinning, directed to tree free growth, where trees are subjected to lower stress levels (e.g., competition for light, water and nutrients) will enhance higher pine nut and kernel efficiencies at tree level. Also, the low densities of umbrella pine stands are well suited to agroforestry and silvopastoral systems as it is possible to associate high pine nut yield and an efficient production of pasture and grazing, due to its low forest stand density, as well as simultaneously providing other services, such as regulation of climate, hydrological and nutrient cycles, soil conservation and reduction of fire risk. However, there are some gaps in knowledge, thus future research should study the effects of stand management on pine nut and kernel productions, in 
particular the effects of biotic and abiotic disturbances.

Acknowledgements The authors are thankful to all members of the Pinus pinea project team, to Companhia Agrícola do Monte Novo, Comonte S.A., Sociedade de Agricultura de Grupo Bicha and Filhos and to the Autoridade Florestal Nacional where trials were settled, to the team that carried out the laboratory work. The work was financed by PROGRAMA AGRO 200 (Project AGRO/200/2001: “Colheita mecânica da pinha (Pinus pinea L.)"'). This work is funded by National Funds through FCT - Foundation for Science and Technology under the Project UIDB/05183/2020 (MED) and UID/MAT/ 04674/2019 (CIMA). The authors acknowledge two anonymous reviewers for their comments.

\section{References}

Adhikari B, Lodhiyal N, Lodhiyal LS (2019) Assessment of crop yield, productivity and carbon sequestration in agroforestry systems in Central Himalaya, India. Agrofor Syst 2:281-296. https://doi.org/10.1007/s10457-019-00388-2

Agrimi M, Ciancio O (1994) Le pin pignon (Pinus pinea L.). Silva Mediterranea, Comité des questions forestières méditerranéennes, Larnaca, Chipre

Aryal DR, Gómez-González RR, Hernández-Nuriasmú R, Morales-Ruiz DE (2019) Carbon stocks and tree diversity in scattered tree silvopastoral systems in Chiapas, Mexico. Agrofor Syst 93:213-227. https://doi.org/10.1007/s10457018-0310-y

Baguskas SA, Still CJ, Fischer DT et al (2016) Coastal fog during summer drought improves the water status of sapling trees more than adult trees in a California pine forest. Oecologia 181:137-148

Bilir N, Prescher F, Lindgren D, Kroon J (2008) Variation in cone and seed characters in clonal seed orchards of Pinus sylvestris. New For 36:187-199. https://doi.org/10.1007/ s11056-008-9092-9

Boutheina A, El Aouni MH, Balandier P (2013) Influence of stand and tree attributes and silviculture on cone and seed productions in forests of Pinus pinea L. in northern Tunisia. In: Mutke S, Piqué M, Calama R (eds) Mediterranean stone pine for agroforestry (Options Méditerranéennes: Série A. Séminaires Méditerranéens; n. 105). CIHEAM, FAO, INIA, IRTA, CESEFOR, CTFC, Zaragoza, pp 9-14

Bueis T, Turrión MB, Bravo F et al (2018) Factors determining enzyme activities in soils under Pinus halepensis and Pinus sylvestris plantations in Spain: a basis for establishing sustainable forest management strategies. Ann For Sci 75:34. https://doi.org/10.1007/s13595-018-0720-z

Calama R, Montero G (2007) Cone and seed production from stone pine (Pinus pinea L.) stands in Central Range (Spain). Eur J For Res 126:23-35. https://doi.org/10.1007/ s10342-005-0100-8

Calama R, Gordo FJ, Mutke S, Montero G (2008) An empirical ecological-type model for predicting stone pine (Pinus pinea L.) cone production in the Northern Plateau (Spain).
For Ecol Manag 255:660-673. https://doi.org/10.1016/j. foreco.2007.09.079

Calama R, Mutke S, Tomé J et al (2011) Modelling spatial and temporal variability in a zero-inflated variable: the case of stone pine (Pinus pinea L.) cone production. Ecol Model 222:606-618. https://doi.org/10.1016/j.ecolmodel.2010. 09.020

Calama R, Puértolas J, Madrigal G, Pardos M (2013) Modeling the environmental response of leaf net photosynthesis in Pinus pinea L. natural regeneration. Ecol Model 251:9-21. https://doi.org/10.1016/j.ecolmodel.2012.11.029

Calama R, Fortin M, Pardos M, Manso R (2017) Modelling spatiotemporal dynamics of Pinus pinea cone infestation by Dioryctria mendacella. For Ecol Manag 389:136-148. https://doi.org/10.1016/j.foreco.2016.12.015

Cañellas I, Cañadas N, Bachiller A, Montero G (2000) Caracterização química de los piñones de Pinus pinea L. In: Para el sur y centro de España In Actas 1 er Simposio del Pino Piñonero Valladolid. pp 221-226

Castro-García S, Blanco-Roldán GL, Gil-Ribes JA (2012) Vibrational and operational parameters in mechanical cone harvesting of stone pine (Pinus pinea L.). Biosyst Eng 112:352-358. https://doi.org/10.1016/j.biosystemseng. 2012.05.007

Costa R, Evaristo I, Batista D et al (2008) Condução de povoamentos de Pinheiro manso e características nutricionais do pinhão. Instituto Nacional dos Recursos Biológicos, I.P. INRB, I.P., Olhão

Cubbage F, Balmelli G, Bussoni A et al (2012) Comparing silvopastoral systems and prospects in eight regions of the world. Agrofor Syst 86:303-314. https://doi.org/10.1007/ s10457-012-9482-z

De-Dios-García J, Pardos M, Calama R (2015) Interannual variability in competitive effects in mixed and monospecific forests of Mediterranean stone pine. For Ecol Manag 358:230-239. https://doi.org/10.1016/j.foreco. 2015.09.014

del Campo AD, Navarro Cerrillo RM, Hermoso J, Ibáñez AJ (2007) Relationships between site and stock quality in Pinus halepensis Mill. reforestation on semiarid landscapes in eastern Spain. Ann For Sci 64:719-731. https:// doi.org/10.1051/forest:2007052

den Herder M, Moreno G, Mosquera-Losada RM et al (2017) Current extent and stratification of agroforestry in the European Union. Agric Ecosyst Environ 241:121-132. https://doi.org/10.1016/j.agee.2017.03.005

Eichhorn MP, Paris P, Herzog F et al (2006) Silvoarable systems in Europe-past, present and future prospects. Agrofor Syst 67:29-50. https://doi.org/10.1007/s10457-005-11117

Eugenio M, Lloret F (2006) Effects of repeated burning on Mediterranean communities of the northeastern Iberian Peninsula. J Veg Sci 17:755-764. https://doi.org/10.1111/j. 1654-1103.2006.tb02499.x

Evaristo I, Tenreiro R, Costa R (2008) Characterisation of biometric parameters and fatty acids content of Pinus pinea L. pine nuts of Portuguese populations. Silva Lusit 16:1-19

Evaristo I, Batista D, Correia I et al (2010) Chemical profiling of Portuguese Pinus pinea L. nuts. J Sci Food Agric 90:1041-1049. https://doi.org/10.1002/jsfa.3914 
Ford MM, Zamora DS, Current D et al (2019) Impact of managed woodland grazing on forage quantity, quality and livestock performance: the potential for silvopasture in Central Minnesota, USA. Agrofor Syst 93:67-79. https:// doi.org/10.1007/s10457-017-0098-1

Ganatsas P, Thanasis G (2010) Pinus halepensis invasion in Pinus pinea habitat in Strofylia forest (Site of NATURA 2000 network), southern Greece. J Nat Conserv 18:106-117. https://doi.org/10.1016/j.jnc.2009.04.006

Ganatsas P, Tsakaldimi M, Thanos C (2008) Seed and cone diversity and seed germination of Pinus pinea in Strofylia Site of the Natura 2000 Network. Biodivers Conserv 17:2427-2439. https://doi.org/10.1007/s10531-008-93908

Gonçalves AC, Pommerening A (2012) Spatial dynamics of cone production in Mediterranean climates: a case study of Pinus pinea L. in Portugal. For Ecol Manag 266:83-93. https://doi.org/10.1016/j.foreco.2011.11.007

Gonçalves AC, Dias AB, Afonso A et al (2016) Mechanical versus manual harvest of Pinus pinea cones. Biosyst Eng 143:50-60. https://doi.org/10.1016/j.biosystemseng.2016. 01.004

Gonçalves AC, Afonso A, Pereira DG, Pinheiro A (2017) Influence of umbrella pine (Pinus pinea L.) stand type and tree characteristics on cone production. Agrofor Syst 91:1019-1030. https://doi.org/10.1007/s10457-016-99752

Goubitz S, Werger MJA, Shmida A, Ne'eman G (2002) Cone abortion in Pinus halepensis: the role of pollen quantity, tree size and cone location. Oikos 97:125-133. https://doi. org/10.1034/j.1600-0706.2002.970113.x

Haymes KL, Fox GA (2012) Variation among individuals in cone production in Pinus palustris (Pinaceae). Am J Bot 99:640-645. https://doi.org/10.3732/ajb.1100339

Johnson RA, Wichern DW (2007) Applied multivariate statistical analysis, 6th edn. Pearson Prentice-Hall, Upper Saddle River

Jose S (2009) Agroforestry for ecosystem services and environmental benefits: an overview. Agrofor Syst 76:1-10. https://doi.org/10.1007/s10457-009-9229-7

Jose S, Gillespie AR, Pallardy SG (2004) Interspecific interactions in temperate agroforestry. Agrofor Syst 61:237-255. https://doi.org/10.1023/B:AGFO.0000029002.85273.9b

Jose S, Walter D, Kumar BM (2019) Ecological considerations in sustainable silvopasture design and management. Agrofor Syst 93:317-331. https://doi.org/10.1007/s10457016-0065-2

Liu Y, Li Y, Song J et al (2018) Geometric morphometric analyses of leaf shapes in two sympatric Chinese oaks: Quercus dentata Thunberg and Quercus aliena Blume (Fagaceae). Ann For Sci 75:90. https://doi.org/10.1007/ s13595-018-0770-2

López-Santiago JG, Casanova-Lugo F, Villanueva-López G et al (2019) Carbon storage in a silvopastoral system compared to that in a deciduous dry forest in Michoacán, Mexico. Agrofor Syst 93:199-211. https://doi.org/10. 1007/s10457-018-0259-x

Manso R, Pukkala T, Pardos M et al (2014) Modelling Pinus pinea forest management to attain natural regeneration under present and future climatic scenarios. Can J For Res 44:250-262. https://doi.org/10.1139/cjfr-2013-0179
Mayoral C, Pardos M, Sánchez-González M et al (2016) Ecological implications of different water use strategies in three coexisting mediterranean tree species. For Ecol Manag 382:76-87. https://doi.org/10.1016/j.foreco.2016. 10.002

Miah MG, Islam MM, Rahman MA et al (2018) Transformation of jackfruit (Artocarpus heterophyllus Lam.) orchard into multistory agroforestry increases system productivity. Agrofor Syst 92:1687-1697. https://doi.org/10.1007/ s10457-017-0118-1

Montero GG, Martinez F, Alía R et al (2004) El Pino piñonero (Pinus pinea L.) en Andalucía: ecología, distribución y selvicultura. Consejeria de médio Ambiente. Junta de Andalucia, Seville

Mutke S, Gordo J, Gil L (2005a) Variability of Mediterranean stone pine cone production: yield loss as response to climate change. Agric For Meteorol 132:263-272. https://doi. org/10.1016/j.agrformet.2005.08.002

Mutke S, Sievänen R, Nikinmaa E et al (2005b) Crown architecture of grafted stone pine (Pinus pinea L.): shoot growth and bud differentiation. Trees 19:15-25

Mutke S, Calama R, González-Martínez SC et al (2012) Mediterranean stone pine: botany and horticulture. Hortic Rev 39:153-201

Nasri N, Triki S (2007) Les protéines de réserve du pin pignon (Pinus pinea L.). C R Biol 330:402-409

Nergiz C, Dönmez İ (2004) Chemical composition and nutritive value of Pinus pinea L. seeds. Food Chem 86:365-368. https://doi.org/10.1016/j.foodchem.2003.09.009

Nerlich K, Graeff-Hönninger S, Claupein W (2013) Agroforestry in Europe: a review of the disappearance of traditional systems and development of modern agroforestry practices, with emphasis on experiences in Germany. Agrofor Syst 87:475-492. https://doi.org/10.1007/s10457012-9560-2

Noland TL, Parker WC, Morneault AE (2006) Natural variation in seed characteristics of Eastern White Pine (Pinus strobus L.). New For 32:87-103. https://doi.org/10.1007/s11056005-4169-1

Orefice J, Smith RG, Carroll J et al (2019) Forage productivity and profitability in newly-established open pasture, silvopasture, and thinned forest production systems. Agrofor Syst 93:51-65. https://doi.org/10.1007/s10457-016-00527

Ortiz O, Ojeda G, Espelta JM, Alcañiz JM (2012) Improving substrate fertility to enhance growth and reproductive ability of a Pinus halepensis Mill. afforestation in a restored limestone quarry. New For 43:365-381. https:// doi.org/10.1007/s11056-011-9286-4

Owens JN, Fernando D (2007) Pollination and seed production in western white pine. Can J For Res 37:260-275. https:// doi.org/10.1139/x06-220

Owens JN, Kittirat T, Mahalovich MF (2008) Whitebark pine (Pinus albicaulis Engelm.) seed production in natural stands. For Ecol Manag 255:803-809. https://doi.org/10. 1016/j.foreco.2007.09.067

Pang K, Van Sambeek JW, Navarrete-Tindall NE et al (2019a) Responses of legumes and grasses to non-, moderate, and dense shade in Missouri, USA. II. Forage yield and its species-level plasticity. Agrofor Syst 93:25-38. https://doi. org/10.1007/s10457-017-0068-7 
Pang K, Van Sambeek JW, Navarrete-Tindall NE et al (2019b) Responses of legumes and grasses to non-, moderate, and dense shade in Missouri, USA. I. Forage yield and its species-level plasticity. Agrofor Syst 93:11-24. https://doi. org/10.1007/s10457-017-0067-8

Pantera A, Burgess PJ, Losada RM et al (2018) Agroforestry for high value tree systems in Europe. Agrofor Syst 92:945-959. https://doi.org/10.1007/s10457-017-0181-7

Pardos M, Calama R, Climent J (2009) Difference in cuticular transpiration and sclerophylly in juvenile and adult pine needles relates to the species-specific rates of development. Trees 23:501-508. https://doi.org/10.1007/s00468-0080296-6

Parker WC, Noland TL, Morneault AE (2013) Comparative mast seed production in unmanaged and shelterwood white pine (Pinus strobus L.) stands in central Ontario. New For 44:613-628. https://doi.org/10.1007/s11056-013-9366-8

Pasalodos-Tato M, Pukkala T, Calama R et al (2016) Optimal management of Pinus pinea stands when cone and timber production are considered. Eur J For Res 135:607-619

R Core Team (2016) R: a language and environment for statistical computing. R Foundation for Statistical Computing, Vienna

Rajora OP, Mosseler A, Major JE (2002) Mating system and reproductive fitness traits of eastern white pine (Pinus strobus) in large, central versus small, isolated, marginal populations. Can J Bot 80:1173-1184. https://doi.org/10. 1139/b02-105

Redmond MD, Weisberg PJ, Cobb NS et al (2016) A robust method to determine historical annual cone production among slow-growing conifers. For Ecol Manag 368:1-6. https://doi.org/10.1016/j.foreco.2016.02.028

Reisner Y, de Filippi R, Herzog F, Palma J (2007) Target regions for silvoarable agroforestry in Europe. Ecol Eng 29:401-418. https://doi.org/10.1016/j.ecoleng.2006.09. 020

Rodrigues A, Silva G, Casquilho M et al (2014) Linear mixed modelling of cone production for Stone Pine in Portugal. Silva Lusit 22:1-27
Saraiva I (1997) O pinhão. Litexa Editora, Lda., Lisboa

Sheskin DJ (2007) Handbook of parametric and nonparametric statistical procedures. Chapman \& Hall, Boca Raton

Sirois L (2000) Spatiotemporal variation in black spruce cone and seed crops along a boreal forest - tree line transect. Can J For Res 30:900-909. https://doi.org/10.1139/x00-015

SNIRH (2007) Sistema Nacional de Informação de Recursos Hidrológicos. In: Agência Port. do Ambient. Gov. Port. Ministério do Ambient. Ordenam. do Territ. e Energ. http:// snirh.pt/. Accessed 15 Jul 2019

Taye ZM, Martínez-Peña F, Bonet JA et al (2016) Meteorological conditions and site characteristics driving edible mushroom production in Pinus pinaster forests of Central Spain. Fungal Ecol 23:30-41. https://doi.org/10.1016/j. funeco.2016.05.008

Turner MG, Turner DM, Romme WH, Tinker DB (2007) Cone production in young post-fire Pinus contorta stands in Greater Yellowstone (USA). For Ecol Manag 242:119-126. https://doi.org/10.1016/j.foreco.2006.12. 032

Ugese FD, Baiyeri PK, Mbah BN (2010) Agroecological variation in the fruits and nuts of shea butter tree (Vitellaria paradoxa C.F. Gaertn.) in Nigeria. Agrofor Syst 79:201-211. https://doi.org/10.1007/s10457-009-9261-7

Wright SP (1992) Adjusted p-values for simultaneous inference. Biometrics 48:1005-1013

Zlotin RI, Parmenter RR (2008) Patterns of mast production in pinyon and juniper woodlands along a precipitation gradient in central New Mexico (Sevilleta National Wildlife Refuge). J Arid Environ 72:1562-1572. https://doi.org/10. 1016/j.jaridenv.2008.02.021

Zuur AF, Ieno EN (2016) Beginner's guide to zero-inflated models with R. Highland Statistics Limited, Newburgh

Publisher's note Springer Nature remains neutral with regard to jurisdictional claims in published maps and institutional affiliations. 